\title{
Social Distancing v. Physical Distancing - Why is the Term Social Distancing Globally Accepted in Times of the COVID-19 \\ Pandemic?
}

\author{
Manuela Svoboda \\ PhD Lecturer of Faculty of Humanities and \\ Social Sciences, University of Rijeka
}

\begin{abstract}
Many measures are being taken during the worldwide COVID-19 pandemic in 2020. One of the primary concepts that appeared throughout the media was "social distancing". Over the months, this term rose to become an omnipresent catchword, used over and over in the news on TV, the radio, in newspapers and journals as well as in everyday communication. In this article the term "social distancing" will be examined in relation to the term "physical distancing". Is it "social distancing" or "physical distancing" that is preventing us from being infected with the virus? The term "social distancing" is analysed from a linguistic, socio-historical and psychological point of view and its use is questioned in the context of the dominant imperative. Furthermore, an attempt will be made to uncover when and in which context the term "social distance" was established and why it has been adopted worldwide during the COVID-19 pandemic, whereas the term "physical distancing", which the author considers to be more appropriate within the context of the recommended measures, was neglected, even though this is the term the WHO is using in their instructions and guidelines.
\end{abstract}

Keywords: COVID-19, social distancing, physical distancing, imperative, pandemic

\section{Introduction}

During the COVID-19 pandemic one term among an array of slogans such as flatten the curve, wash your hands, be responsible/stay responsible, wear a mask, new normal has gone viral globally: social distancing. It was one of the initial and imperative measures for preventing the spread of the virus issued by the health ministers and the Crisis Management Committees around the world.

Countries worldwide introduced this term and adopted it: soziale Distanz (German), socijalna distanca (Croatian/Serbian/Bosnian), distance sociale (French), distanca soziale (Italian), distancia social (Spanish), distância social (Potugese), социальная дистанция (Russian), dystans społeczny (Polish) and the list goes on. But why exactly is it termed social distance and is it possible to utilize a term such as this in all languages and cultures for the same purpose?

Nowadays, it is easy to spread the word through social media and media in general. A picture, slogan or even fake news goes viral within seconds and considering that the English language is used as a lingua franca, most of the things we see and read in social media, or the media in 
general, are precisely in this language. More often than not, certain terms are not even translated. However, the rules seem to differ with regards to the term social distancing, as it was translated into plenty of languages all over the world. This was supposedly done to make sure that everyone, including the older population and those who do not speak English, understand it.

Yet, this raises the question of whether the term was transferred/translated correctly to the other languages. Does it really signify the same meaning if we speak of social distancing, soziale Distanz or socijalna distanca?

When consulting the web concerning the term social distancing, one will uncover plenty of definitions and explanations related to the COVID-19 pandemic. This is the result of the current hype regarding the pandemic additionally being pumped up by the media ${ }^{1}$ :

"Social distancing, also called "physical distancing," means keeping a safe space between yourself and other people who are not from your household.

To practice social or physical distancing, stay at least 6 feet (about 2 arms' length) from other people who are not from your household in both indoor and outdoor spaces.

Social distancing should be practiced in combination with other everyday preventive actions to reduce the spread of COVID-19, including wearing masks, avoiding touching your face with unwashed hands, and frequently washing your hands with soap and water for at least 20 seconds."

(https://www.cdc.gov/coronavirus/2019-ncov/prevent-getting-sick/social-distancing.html)

The confusion with respect to this term began at the very moment it was spread all over the media. Thus, various authors and academics reacted to this immediately, one of which was the legal expert Wolfgang Mazal from the University in Vienna:

"'Social distancing" ist eine Wendung der Fachsprache unter anderem der Epidemiologie, die in den letzten Tagen in die öffentliche Debatte Eingang gefunden hat; allerdings wäre da semantisch mehr Sorgfalt geboten, weil in der Fachsprache andere gedankliche Assoziationen ablaufen als in der Alltagssprache. Stimmt es wirklich, dass "social distancing" das Gebot der Stunde ist, um katastrophale Bilder, wie wir sie aus Italien und Spanien sehen, in Österreich nicht Realität werden. [...] Fest steht jedenfalls, dass vor dem Hintergrund des lateinischen Wortstamms "soc", der "Verbundenheit" signalisiert, eher das Gegenteil von sozialer Distanz zu beobachten ist: Familien, Freund*innen, Kolleg*innen, fühlen sich in den letzten Tagen stärker denn je für einander verantwortlich und rücken gedanklich immer näher zusammen. [...] Ich finde daher, wir sollten das Wording wechseln und ab nun eher von "physical distancing" sprechen. Diese Wendung trifft die tatsächlichen Gegebenheiten besser und ist auch zukunftsfester: Gerade in den auf uns zukommenden Monaten wäre es nämlich fatal, wenn sich die Denkfigur von der sozialen Distanz im Denken eingenistet hat, selbst wenn physische Nähe wieder möglich sein wird! (https://medienportal.univie.ac.at/uniview/wissenschaftgesellschaft/detailansicht/artikel/soziale-distanz-das-falsche-wording)

\footnotetext{
${ }^{1}$ It was very interesting to see that it is completely impossible to find the term social distance or social distancing in any other context but in the COVID-19 context on Google. No matter what you type, how you try to find another context, it is just impossible, the results are always the same and always relating to the present pandemic. In order to find literature on social distancing in the socio-historical context other search engines but Google had to be consulted.
} 
("Social distancing" is a technical term used in epidemiology, among other fields, which has entered the public debate in recent days. However, semantically it should be treated with more care, as the occurring associations in technical language are different from those in everyday language. Is it true that "social distancing" is the order of the day to prevent catastrophic images, such as in Italy and Spain, from becoming reality in Austria? [...] In any case, it is clear that given the fact that the Latin word stem "soc" signals "solidarity", the opposite of social distance can be observed: families, friends and colleagues feel responsible for each other more than ever before and are moving closer together in their thoughts. [...] I therefore think we should, from now on, change the wording and rather speak of "physical distancing". This term is better suited to the actual circumstances and is also more future-proof: Especially in the months ahead, it would be fatal if the mental figure of social distance became embedded in the thoughts, even if physical proximity will be possible again! ${ }^{1}$ )

The term social distancing IS used as technical term in the medical field as can be found in the Merriam-Webster Dictionary:

"Social distancing, noun, definition of social distancing, medical: the practice of maintaining a greater than usual physical distance (such as six feet or more) from other people or of avoiding direct contact with people or objects in public places during the outbreak of a contagious disease in order to minimize exposure and reduce the transmission of infection: PHYSICAL DISTANCING." (https://www.merriam-webster.com/dictionary/social\%20distancing\#h1)

It also states that the first known use of the term in the sense described above was in 2004 during the swine flu pandemic and has obviously been transferred to the COVID-19 pandemic in 2020. The term social distancing was not used prior to this during other pandemics. According to Furedi, the sociologist Karl Mannheim was the first to use the aforementioned term in a similar context in the 1950s:

"Mannheim was probably the first sociologist to explore the relationship between social distance and what today is characterised as "safe space". Writing in the 1930s and preoccupied by the threat of totalitarian movements, Mannheim referred to safe space in his discussion of social distance, which he claimed could signify both "an external or spatial distance" or an "internal or mental distance". Mannheim believed that the impulse towards distancing was bound up with the need to regulate and control anxiety. [...] It was in the context of the fears that emerged in the inter-war era that Mannheim located the aspiration for a safe space." (Furedi 2020: 393)

Even Wikipedia attempts to indicate that differences exist between the terms social distancing and social distance or social isolation and seeks to clarify them:

"Not to be confused with Social distance or Social isolation.

In public health, social distancing, also called physical distancing,[2][3][4] is a set of nonpharmaceutical interventions or measures intended to prevent the spread of a contagious disease by maintaining a physical distance between people and reducing the number of times people come into close contact with each other.[2][5] It typically involves keeping a certain distance from others (the distance specified may differ from time to time and country to country) and avoiding gathering together in large groups."

\footnotetext{
${ }^{1}$ Free translation by the author.
} 
(https://en.wikipedia.org/wiki/Social_distancing)

But why then is it deemed social distancing and not physical distancing? It surely does not mean the same if you distance yourself socially or physically, yet the two terms are used synonymously all over the media. Moreover, the term physical distancing is used very seldomly or not at all.

On the other hand, when consulting the web pages of the World Health Organization they, interestingly enough, do NOT use the term social distancing but state the following:

"Maintain at least 1 metre (3 feet) distance between yourself and others. Why? When someone coughs, sneezes, or speaks they spray small liquid droplets from their nose or mouth which may contain virus. If you are too close, you can breathe in the droplets, including the COVID-19 virus if the person has the disease.

Avoid going to crowded places. Why? Where people come together in crowds, you are more likely to come into close contact with someone that has COVID-19 and it is more difficult to maintain physical distance of 1 metre (3 feet)."

(https://www.who.int/emergencies/diseases/novel-coronavirus-2019/advice-for-public)

The World Health Organization does, in fact, use the (proper) term physical distance, as opposed to that which is used by politicians and the mass media.

\section{Methodology}

This research is a qualitative research. The purpose of this research was to study the use of the term social distancing versus the term physical distancing in times of the Covid-19 pandemic in the English, German and Croatian language with regards to the historical, socioeconomic and psychological implications it has. In addition, the attempt was made to explore when the term social distancing was introduced and why it was accepted in all three languages. Data was collected and analysis performed based on available material, i.e. research articles and newspaper articles as well as information available on government and institutional web pages.

\section{Social distancing v. physical distancing - a definition of terms}

Let us look at the term social distancing from a linguistic point of view. In the German language ${ }^{1}$ especially, the word sozial has a deeper and more significant meaning than the English word social.

If we look up synonyms for the word social in English, the most relevant ones are: civil, communal, collective, common, community, cordial, familiar, general, group, nice, sociable, societal, amusing, communicative, companionable, convivial, diverting, entertaining, gracious, gregarious, hospitable, organized, pleasant, pleasurable, popular etc. (https://www.thesaurus.com/browse/social)

Hence, this term may work in the English-speaking world, as it can be used to express the avoidance of crowded places and close contact with other individuals, yet, the term physical distancing conveys, in a better sense, what is intended. When we look up the term physical in the same sources, the thesaurus gives us the following synonyms in English: environmental,

\footnotetext{
${ }^{1}$ The author will limit comments to the German and the Croatian language as these are her native languages.
} 
natural, real, substantial, concrete, corporeal, gross, materialistic, objective, palpable, phenomenal, ponderable, sensible, solid, somatic, visible.

(https://www.thesaurus.com/browse/physical?s=t)

Therefore, this instead refers to spatial distance which is (or is not?) what is implied by the term social distancing in times of the pandemic.

If we search for the synonyms of the word sozial in German it is apparent that they differ somewhat from the English term: uneigennützig, mitleidig, anteilnehmend, mitfühlend, sanftmütig, sanft, barmherzig, mildtätig, menschlich, gutherzig, menschenfreundlich, altruistisch etc. (https://www.synonyme.de/sozial)

This connotation is intended to more or less signify a sense of compassion or sympathy, which does not highlight the intended meaning, but rather leads us in another direction: should people distance themselves from being humane and not empathize with others? Do health ministers and other politicians really want us to be compassionless and selfish amid the pandemic?

If we consider the term physisch, the corresponding synonyms are i.a.: körperlich, leiblich, leibhaftig, greifbar, gegenständlich, natürlich, organisch, materiell, körperhaft, inhaltlich, körperhaft, wirklich, etc. (https://www.synonyme.de/physisch/) Again, we can observe that the connotation for physische Distanz would be intended to suggest a sense of spatial and bodily distance, as opposed to the connotation soziale Distanz, which it originally has in German. As a matter of fact, in German the term körperlich exists which more precisely describes this bodily distance and yet it is not used.

Let us have a look at a third language, Croatian, in which the term socijalna distanca was also adopted. The synonyms we uncover, depending on context, are: društveno, klasno, kulturalno, intelektualno, moralno, nacionalno, razvojno, ekonomsko, rodno, materijalno, životno, emocionalno, političko, jezično etc. (https://www.kontekst.io/hrvatski/socijalno)

It is evident that the word socijalno has a very wide range of meanings in the Croatian language, ranging from political to emotional and economical, i.a. meaning cultural, emotional, political national, economical and even referring to class affiliation. Again, it does not bear the same meaning as the English word social considering that an array of areas can be covered by this term thus rendering it unclear to the average person. One cannot assume that everyone is familiar with technical medical terms used in epidemiology.

The term fizičko is synonymous with the following: tjelesno, praktički, mentalno, očito, praktično, tehnički etc. (https://www.kontekst.io/hrvatski/fizicki) In Croatian as well, the synonym of fizičko is tjelesno, referring to bodily distance, i.e. two bodies keeping distance between each other or in English physical distancing. Still, the Croats, as in all the other countries, adopted the term socijalna distanca.

The German author Regula Venske gets to the heart of it in a newspaper article:

„Während wir im Deutschen mit dem Wort "sozial" einen sehr aufgeladenen Begriff haben. Wenn wir an unsere Parteien denken, von der Sozialdemokratie bis zur Christlich-Sozialen Union, die Soziale Marktwirtschaft - da ist "sozial" immer assoziiert mit gesellschaftlicher Solidarität, mit Verantwortung, mit Fürsorge und Gemeinsinn. Wenn wir jetzt von "sozialer Distanz" sprechen, dann könnte das ein ganz falsches Signal geben. Es könnte Menschen, die sich sowieso schon an 
der Einkommensgrenze befinden oder die sich abgehängt fühlen und jetzt große Ängste haben, in diesem Gefühl der Mutlosigkeit oder der Panik bestärken. Statt "sozialer Distanz" sollten wir eher "physische" oder "räumliche Distanz" sagen, oder "körperlicher Abstand". Es gibt schlichte deutsche Worte, die jetzt viel passender sind." (https://www.ndr.de/kultur/Corona-DieWirkung-von-Sprache-in-Krisenzeiten,venske118.html)

(In German, the word "social" is a very strong, emotionally charged term. When we think of our parties, from the Social Democrats to the Christian Social Union, or the social market economy - "social" is always associated with social solidarity, responsibility, care and public spirit. If we now speak of "social distance", this could send a completely wrong signal. It could encourage people who are already at the income limit or who feel abandoned and are in great fear, to feel discouraged or panicky. Instead of "social distance" we should rather say "physical" or "spatial distance". There are simple German words that are much more appropriate now ${ }^{1}$.)

In conclusion, it can be said that the meaning of the English word social does not correspond to the meaning of the German word sozial or that of the Croatian word socijalno. Hence, it would have been more appropriate to use the term physical distancing rather than social distancing in, at least, the German and the Croatian language in order to avoid confusion. Of course, one can argue that this term is used as a technical term in epidemiology and other scientific fields, but is it appropriate to use it for the broader masses who are not familiar with these sciences? The term social is considered new in technical medical language as well, as it was not introduced prior to 2004 or during any other pandemic. In the author's opinion, the usage of this specific and ambiguous term leads to confusion, uncertainty and even greater panic among the population, which is counterproductive in the current scenario of a worldwide pandemic.

\section{Social distancing -from the socio-historical point of view}

If we look at the omnipresent term social distancing or social distance from a socio-historical perspective, one comes to the understanding that it was formerly used to define class distinction and was even used to address race as the term social distancing has a long history and, one might assert, has lived several lives:

"It and its precursor, 'social distance', had long been used in a variety of colloquial and academic contexts, both as prescriptions and descriptions, before being taken up by epidemiologists in this century. In the nineteenth century, "social distance" was a polite euphemism used by the British to talk about class and by Americans to talk about race." (Scherlis 2020:1)

Furthermore, in her article, Scherlis illustrates the socio-historical aspect as well as the connotations attached to the term social distancing in the 19th century Anglophone world which, back then, was used to refer to social class as well as to racism. It was usual practice to separate the noblesse from working people and the term social distancing or social distance had dual meanings:

"Social distance is both a prescription for interpersonal behavior and a way to figure mass inequality." (Scherlis 2020:3)

\footnotetext{
${ }^{1}$ Free translation by the author.
} 
In addition, the term was used in the United States to express the continuing superiority of white people after the abolition of slavery:

"The term's softness glossed over the realities of slavery and later anti-black violence, as well as the challenges formerly enslaved people faced in making a livelihood." (ibid.)

A closer definition of social distancing in the sense of racism is to be found in Park and Burgess' book Introduction to the Science of Sociology from 1921:

"The simplest and most fundamental types of behavior of individuals and of groups are represented in these contrasting tendencies to approach an object or to withdraw from it. If instead of thinking of these two tendencies as unrelated, they are thought of as conflicting responses to the same situation, where the tendency to approach is modified and complicated by a tendency to withdraw, we get the phenomenon of social distance. There is the tendency to approach, but not too near. There is a feeling of interest and sympathy of $A$ for $B$, but only when B remains at a certain distance. Thus, the Negro in the southern states is "all right in his place." The northern philanthropist is interested in the advancement of the Negro but wants him to remain in the South. At least he does not want him for a neighbor. The southern white man likes the Negro as an individual, but he is not willing to treat him as an equal. The northern white man is willing to treat the Negro as an equal but he does not want him too near. The wishes are in both cases essentially the same but the attitudes are different." (Park/Burgess 1921: 440)

Sadly, even today many people still tend to garner these beliefs. In the United States, coloured people might still be an issue to some whites and in Europe there are other races that are not regarded as equal, especially in reference to the ongoing migration wave throughout Europe.

Worth mentioning is a study done by Robert Park and his former student Emory S. Bogardus at the beginning of the $20^{\text {th }}$ century which was performed due to a surge of non-Protestant, e.g. Asian, immigration to the United States. The scientist Bogardus established the so-called Social Distance Scale which made it possible to measure how distance is related to prejudices. Thus, they established degrees of intimacy and asked respondents to define how much intimacy/distance they would deem acceptable with regards to members of a certain group:

"The Social Distance Scale usually consists of five to seven statements that express progressively more or less intimacy toward the group considered. Typical scale anchors are "would have to live outside of my country (7)" and "would marry (1)" (Cover 1995:403). In this case, a respondent who accepts item "seven" would be more prejudiced than a respondent who marks item "one" or any other item on the scale. The cumulative aspect also means that a respondent who expresses a given degree of intimacy will endorse items expressing less intimacy. A respondent willing to accept a member of a group in their neighborhood will also accept that same group in their country. Conversely, those who refuse to accept a group in their country will also refuse to accept them in their neighborhood." (Wark/Galliher 2007:386)

This simple, unidimensional and cumulative scale makes it possible to measure the relations between specific social groups. It can also be transferred to other areas of social life, e.g. schools or hospitals in order to measure the dynamics between teachers and students or doctors and patients and was also used during the 1990s when the AIDS virus emerged in order to measure the hostility of people towards fellow infected citizens.

Initially, the AIDS virus was stigmatized as being transferred between gay men and not until much later was it acknowledged as a chronic disease: 
"Indeed, the disease was initially termed GRID, the gay-related immunodeficiency disease, and those stricken who denied homosexual contacts were often assumed to be lying." (Fee/Krieger 1993: 1478)

This led to social distancing which was caused by fear and stigmatization of infected individuals. Hence, this can be compared to stigmatization and fear of people with the plague or leprosy in the Middle Ages, but unlike then, only a distinct group of people were initially subjected to this type of behaviour.

In 1995 Leiker et al. used the Social Distance Scale in order to measure the behaviour towards people infected with AIDS, which was characterised by antipathy and homophobia:

"First, we found that stigma increased as homophobia increased in all four PWA ${ }^{1}$ conditions ${ }^{2}$. Second, stigma increased as AIDS knowledge decreased in the IV drug use and blood transfusion conditions. Third, women attached less stigma than men in all but the heterosexual condition. Fourth, in the blood transfusion condition, stigma decreased as religiosity increased." (Leiker et al. 1995:333)

People were so apprehensive of this disease that they did not want to find themselves anywhere near an individual with AIDS, even though the infection was transferred by way of bodily fluids such as blood or semen and not through airborne droplets.

When applying the Social Distancing Scale to the COVID-19 pandemic in 2020 it can be downscaled to the options: allowing a person into a radius of $2 \mathrm{~m}$ with a mask or without one, as this virus, according to experts, is airborne and more infectious than other known SARS viruses.

Furthermore, social distancing was practised throughout history in many ways, as can be seen in this chapter, yet

"most of the scholars who studied social distance in the twentieth century hoped to reduce it. [...] To participate in social distancing was to devalue a person; the study of social distance objectified these devaluations on a macro scale." (Scherlis 2020:7)

Now, in the $21^{\text {st }}$ century, social distancing has once again made its grand re-entrance and nowadays is not to be perceived as a devaluation of a person but rather as a kind of superpower used to save the world, albeit the social and historical implications point to anything but this.

\section{Social distancing -from the psychological point of view}

One of the important, if not most important factors concerning social distance that we must consider is psychological. How do people respond to being socially or physically separated from other human beings?

It is well-known that humans are social beings and a basic need is for them to be in contact with others - to talk, hug, shake hands, kiss, etc. and it is precisely these basic needs that are banned during the Covid-19 pandemic. How does a grandmother feel if she is not allowed to hug or kiss her grandchild? How do work colleagues feel when they have to avoid any physical

\footnotetext{
${ }^{1}$ PWA $=$ Persons with AIDS

2 According to the authors the four behaviors for developing AIDS are the following: homosexual sex, IV drug use, heterosexual sex, or a blood transfusion
} 
contact? But most of all, how do children cope with not being allowed to play with their friends, to hug or touch another person?

Communication is also an important element of the human being, it not only being based on words, but also on facial expressions and gestures. How do people perceive suddenly being surrounded by faceless mask wearers? How can one communicate if one cannot observe facial expressions or understand words all too well due to the mouth being covered? Hearing impaired individuals are faced with a tremendous challenge because they largely depend on lip-reading in everyday life, as not everyone is able to communicate with them in sign language.

On the one hand, social contact is prevented and yet on the other hand, primary family contacts have been strengthened during the lockdown. The "locking up" of the family in an apartment or house made it impossible to separate or to be alone, which is also a basic human need. For a time, children did not go to school and parents did not go to work. They all needed to complete their assignments at home. They had to educate themselves, follow online lessons, participate in business meetings, all this while being surrounded by the entire family.

More affluent families have the advantage of living in a larger house, each child having their own room, computer, laptop, tablet, their own garden etc. But what about socially weaker families who may live in a two-room apartment with four children? Those of whom do not have a balcony, let alone a garden? How long can people bear this togetherness? What does it do to them? Certainly, peoples' nerves in this situation are often on edge.

"This COVID-19 pandemic itself may lead to an increase in the number of cases of depressive disorders and anxiety disorders along with loneliness, social isolation, substance abuse, and a rise in domestic violence. They also warn that with the schools closed, there is a risk of a sharp rise in the number of cases of child abuse across the nations." (https://www.newsmedical.net/news/20200412/What-are-the-side-effects-of-social-and-physical-distancing)

According to the newspapers, there has been an obvious rise in domestic violence and child abuse even though additional help phones and advice centres were set up. The true extent of this will most likely only become apparent after a considerable amount of time has passed. Considering that not everyone reports domestic violence or child abuse, the number of unreported cases is most certainly much higher. (cf. https://www.ndr.de/nachrichten/mecklenburg-vorpommern/Offenbar-mehr-haeuslicheGewalt-in-Corona-Krise,coronavirus2562.html)

Regretfully, social distancing is being practiced in its most severe form during the Covid-19 pandemic, and includes but is not limited to:

"Standing apart from others at a 5-foot or higher distance, especially in public areas and while waiting in lines

Limiting the number of people allowed into a location at a time

Limiting the number of people allowed to travel per vehicle

Introducing remote options for work and education

Imposing curfews 
Closing establishments and locations that typically contain a relatively high number of people, such as eateries or swimming pools

Banning gatherings of a certain amount of people or higher

Stopping all services apart from essential services

Enforcing movement restriction orders

Enforcing full lockdowns that prevent individuals from leaving their homes"

(https://www.powerofpositivity.com/social-distancing-affects-mental-health)

As a matter of fact, all personal freedoms which people took for granted have been limited or taken away from them. From one day to the next, people must stay at home, not allowed to do this, not allowed to do that. A feeling of being imprisoned has emerged. This is coupled with a fear for one's own life and for the lives of one's relatives, with whom one was not allowed to be close (socially/physically) just when that was what was needed the most. Apprehension coupled with the feeling of being trapped and not knowing how long this condition will last is most certainly not for individuals with weak nerves.

Suddenly people must change their habits, adjust to a completely new reality and wait to see what will happen. Certainly, there is nothing worse than sitting around, waiting and not being able to alter the situation or help oneself in any way:

"Waiting is one of the most unpleasant experiences people regularly endure: waiting for an exam grade, a medical diagnosis, results from a job interview or audition. There are myriad words in the English language for unpleasant feelings associated with waiting: "fear," "anxiety," "dread," "trepidation." Remarkably and, tellingly, there aren't many words in the English language for a pleasurable state of waiting, though "anticipation" may fall into that category. (https://www.marketwatch.com/story/people-find-waiting-incredibly-unpleasant-abehavioral-economist-on-why-doing-nothing-during-the-coronavirus-pandemic-is-so-hardand-how-to-make-it-easier-2020-04-01)

With regards to the lockdown, the concept of social distance can certainly be viewed in a more differentiated way. Following the lockdown, the focus is, to a greater extent, on physical distance, while during the lockdown it is possible to see social distance in its original form and definition mentioned in chapter 2 . It can be said that physical distance is also guaranteed, but "only" outside of the immediate family or possibly roommates. In this context, the term can also be equated with social isolation, e.g. when it comes to single or elderly people who live in social isolation rather than physically distant isolation as would be the case in retirement or nursing homes. It is especially hard for elderly people as they already have fewer social contacts due to their age, are not employed, their children have families of their own and may not have enough time for them. Not only are they at an increased risk for more severe illness from the virus that this disease causes, due to being immunocompromised and often having underlying conditions, but also of social distancing and isolation:

Almost 25\% of all elderly individuals aged 65 and over experience some degree of social isolation, typically meaning that they already have few interactions with other individuals. Among this group, $40 \%$ of those aged 60 or older say that they feel lonely, too. This means that the elderly are already suffering ill-effects from social isolation, and social distancing can make it much worse." (https://www.powerofpositivity.com/social-distancing-affects-mental-health) 
Not only was the lockdown a challenge for elderly people but also, or maybe especially, for the young. In contrast to older individuals, the younger ones have active social contacts and interactions. They go to school, university, work, enjoy going out and meeting friends. Suddenly none of this was possible anymore. No work, school or university, no cafes, cinemas, shopping centres, no bars, clubs, fitness centres or sports clubs, no hairdressers, nail studios or massages, no swimming pools, amusement parks, concerts, no operas... Even food shopping and going out for a walk was questionable.

As consolation or countermeasure during the lockdown, people referred to social media again and again, because it was a medium by which to stay in touch intensively, to see each other, hear each other etc. Yet, can such virtual contact replace the usual social contact? The question certainly cannot be answered with a clear "yes". Over a certain, shorter period, it may well work, but in the long run it is quite unsatisfactory as people would be eager to see friends and family in person. It is only too human and natural to miss your loved ones and to long for them, to take them in your arms and to sit at a table with them, to see them live and in-person, touch them, smell them, sense them and entirely feel them.

Back to the elderly: how much do they know about technology in order to use social media to stay in touch with their family and friends? One thing is certain: it is without a doubt unhealthy for people to be alone or to be isolated:

"Over long periods of time, social isolation can increase the risk of a variety of health problems, including heart disease, depression, dementia, and even death. A 2015 meta-analysis of the scientific literature by Julianne Holt-Lunstad, a research psychologist at Brigham Young University, and colleagues determined that chronic social isolation increases the risk of mortality by 29\%." (https://www.sciencemag.org/news/2020/03/we-are-social-species-how-willsocial-distancing-affect-us)

Social distancing as practiced during the COVID-19 pandemic assuredly can lead to stress and anxiety, depression, lack of motivation and productivity, anger, turning to vices, loss of cognitive strength and even trauma. It is very difficult to think positively and to stay mentally healthy in such a predicament, let alone the fact that social isolation increases the rate of mortality as well as the suicide rate. (cf. https://www.powerofpositivity.com/socialdistancing-affects-mental-health)

\section{Discussion}

Why of all things the term social distancing has become established in the media and globally accepted during the COVID-19 pandemic and an earlier pandemic, namely the swine flu (when it was used for the first time to refer to physical distance) could not be fully explained based on the available sources that were examined. As established throughout the research, the term social distancing might even work for the English-speaking countries, but soziale Distanz and socijalna distanca surely are not the proper terms in German and Croatian language.

In order to find a satisfactory answer to this question, it would be necessary perhaps to conduct additional research in the field of medical terminology and etymology and/or interview the people responsible for introducing the term during the Covid-19 pandemic in order to elicit from them their motivation for establishing this term in the broader public realm. 
Another interesting research would surely be how this term works in other countries and languages, as (when you check on the internet) the term social distancing is used almost everywhere as mentioned at the beginning of the article.

\section{Conclusion}

Now that the concept of social distance has been examined from various perspectives, we can ascertain that the term can certainly be viewed critically in its socio-historical context and that it has only emerged in a medical context during the $21^{\text {st }}$ century. This concept was used in other contexts in centuries prior, i.a. to refer to class and/or racial difference and did not have a positive connotation as described in chapter 3 of this article.

However, it does seem that over time various countries have reacted to the confusion surrounding the term social distancing, soziale Distanz or socijalna distanca and as a result there are a lot of articles on the internet explaining what is really implied by using the term(s) in connection with the COVID-19 pandemic.

Not only is the term clarified, but clearer instructions and signs were implemented which make understanding of such easier. By now, a new term has been introduced, indicating exactly by way of visualisation what people should do: keep their distance, Abstand halten, držite razmak:

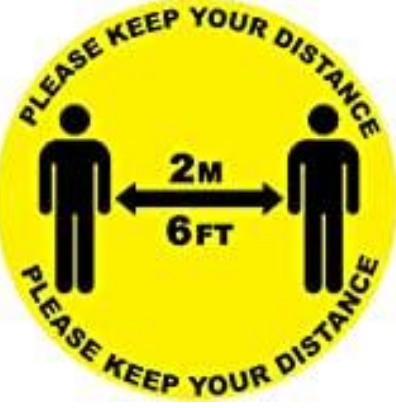

Picture 1

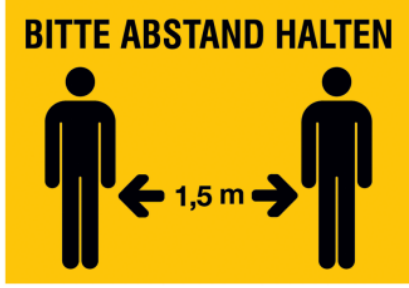

Picture 2

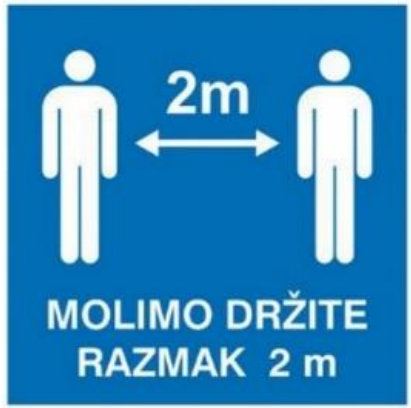

Picture 3

Yet, it is interesting to see, that in some countries the optimal suggested distance is $1.5 \mathrm{~m}$ while in others it is 2, possibly due to differences in measuring within the same country. There seems to be no uniform guideline for people to follow. Another explanation can be found in the fact that the distance guideline initially started with $1 \mathrm{~m}$ at the beginning of the pandemic, then was raised to $1.5 \mathrm{~m}$ and finally to $2 \mathrm{~m}$. Nevertheless, it seems signs are not used or adjusted accordingly. These signs and the statement keep your distance, Abstand halten or držite razmak do not lead to confusions unlike the term social distancing.

Yet, if we pay attention to politicians and the media, they still refer to social distancing, soziale Distanz and socijalna distanca. Most likely they wish to demonstrate that they are familiar with this technical medical term and enjoy sounding like experts in the field or they just want to confuse people on purpose to stay in control of the situation. 
In summation, the author would agree with George Loewenstein, Professor of Economics and Psychology in the Social and Decision Sciences Department at Carnegie Mellon University and director of the Center for Behavioral Decision Research that it would be necessary to replace the term social distancing with physical distancing, to be in compliance with the WHO, or as Loewenstein states:

"A more superficially, but potentially surprisingly efficacious action would be to replace the term "social distancing" with "spatial distancing." As we distance ourselves spatially, we have an even greater need for social contact, and for activities that bring ourselves together and give our lives meaning. Rather than waiting for the other shoe to drop, we need to gear up to support others."

(https://www.marketwatch.com/story/people-find-waiting-incredibly-unpleasant-a-

behavioral-economist-on-why-doing-nothing-during-the-coronavirus-pandemic-is-so-hardand-how-to-make-it-easier-2020-04-01)

While writing this article an interesting phenomenon was witnessed in the media, especially on TV, concerning the mask wearing imperative which led to the assumption that the term social distancing was not chosen accidentally or without intention:

There seems to be a (social) distinction between who must wear a mask and who must not. When we look at TV shows, the people in front of the camera, the hosts and guests do not wear masks, even though the distance between them at times is not the prescribed 1.5 or $2 \mathrm{~m}$, yet all the cameramen, make-up artists, assistants, dancers etc. DO wear masks, even when they are in focus of the camera. With that being said, there definitely IS social distancing happening right now, isn't there?

This is precisely what also happens when politicians come together. Most of them don't wear masks when getting out of a car or entering a building (to be witnessed on TV every day), but the chauffeurs, doormen, cameramen, and journalists all must wear one. Who is being protected? Who is protecting whom? Does the obligation to wear a mask only apply to the lower strata of society, and do the one's better off escape this obligation? Is it not inconsiderable for social distance to be observed here in the historical sense? Isn't a clear distinction being made between the social classes as well? Or are our politicians allowed to play by their own rules regardless of what they require from their citizens? These questions may seem somewhat provocative, but the fact is that this can be seen in the media day in and day out. An average citizen may ask themselves where this all leads and whether the term social distancing is nevertheless connected to some of the linguistic, socio-historical, and psychological meanings mentioned in this article.

\section{References}

[1] Fee, E., Krieger, N. (1993). Understanding AIDS: Historical Interpretations and the Limits of Biomedical Individualism, American Journal of Public Health, 83, pp. 14771486

[2] Furedi, F. (2020). Social Distancing, Safe Spaces and the Demand for Quarantine, Society, 57, pp. 392-397.

[3] Gupta, S. (2020). Social distancing comes with psychological fallout. Retrieved from: https://www.sciencenews.org/article/coronavirus-covid-19-social-distancingpsychological-fallout 
[4] Leiker Jason J., Taub Diane E. \& Gast, Julie (1995). The stigma of AIDS: Persons with AIDS and social distance, Deviant Behavior, 16:4, pp. 333-351

[5] Lee, D. (2020). The Psychological Effects of Social Distancing. Retrieved from: https://www.ardenthospice.com/the-psychological-effects-of-social-distancing/

[6] Loewenstein, G. (2020). 'Replace the term social distancing with spatial distancing.' A behavioral economist on the psychological toll of endless waiting during the coronavirus pandemic. Retrieved from: https://www.marketwatch.com/story/people-findwaiting-incredibly-unpleasant-a-behavioral-economist-on-why-doing-nothingduring-the-coronavirus-pandemic-is-so-hard-and-how-to-make-it-easier-2020-0401

[7] Mandal, A. (2020). What are the side effects of social and physical distancing? Retrieved from: https://www.news-medical.net/news/20200412/What-are-the-side-effectsof-social-and-physical-distancing.aspx

[8] Mazal, W. (2020). Soziale Distanz - das falsche Wording! Retrieved from: https://medienportal.univie.ac.at/uniview/wissenschaftgesellschaft/detailansicht/artikel/soziale-distanz-das-falsche-wording

[9] Miller, G. (2020). Social distancing prevents infections, but it can have unintended consequences. Retrieved from https://www.sciencemag.org/news/2020/03/we-aresocial-species-how-will-social-distancing-affect-us

[10] National Center for Immunization and Respiratory Diseases (NCIRD), Division of Viral Diseases (2020).

[11] "Social Distancing - Keep a Safe Distance to Slow the Spread", 2020. Retrieved from https://www.cdc.gov/coronavirus/2019-ncov/prevent-getting-sick/socialdistancing.html

[12] NDR 1 Radio MV (2020). Offenbar mehr häusliche Gewalt in Corona-Krise. Retrieved from https://www.ndr.de/nachrichten/mecklenburg-vorpommern/Offenbar-mehrhaeusliche-Gewalt-in-Corona-Krise,coronavirus2562.html

[13] Park, R. E., Burgess, E. W. (1921). Introduction to the Science of Sociology, Chicago: University of Chicago Press

[14] "Psychology Explains How Social Distancing Affects Your Mental Health (2020). Retrieved from https://www.powerofpositivity.com/social-distancing-affectsmental-health/

[15] Scherlis, L. (2020). Distantiated Communities: A Social History of Social Distancing. Retrieved from http://cabinetmagazine.org/kiosk/scherlis_lily_30_april_2020.php

[16] Wark, C, Galliher, J. F. (2007). Emory Bogardus and the Origins of the Social Distance Scale, The American Sociologist, 38, p.p. 383-395

[17] WHO (2020). Coronavirus disease (COVID-19) advice for the public (2020). Retrieved from https://www.who.int/emergencies/diseases/novel-coronavirus-2019/advicefor-public

\section{Online Resources}

[1] https://en.wikipedia.org/wiki/Social_distancing

[2] https://www.augsburger-allgemeine.de/dillingen/Appell-von-OB-Frank-KunzSoziale-Kontakte-minimieren-id57100606.html

[3] https://www.creativesafetysupply.com/keep-the-distance-social-distancing-withicons-floor-sign

[4] https://www.kontekst.io/hrvatski/socijalno 
[5] https://www.limes.hr/katalog/oznaka_molimo_drzati_razmak_2m_189415

[6] https://www.synonyme.de/sozial

[7] https://www.thesaurus.com/browse/social

\section{Work of visual art}

[1] Picture 1: Safety signs. Party Décor ${ }^{\mathrm{T} M}$. (2020). Retrieved from https://www.amazon.co.uk/please-keep-your-distancedistancing/dp/B088Q1YYH5

[2] Picture 2: Hinweisschilder "Bitte Abstand halten 1,5 m". Seton. (2020). Retrieved from https://www.seton.de/hinweisschilder-bitte-abstand-halten-1-5-m.html

[3] Picture 3: Oznaka molimo držati razmak od 2m. Limes plus. (2020). Retrieved from https://www.limes.hr/katalog/oznaka_molimo_drzati_razmak_2m_189415 